Postgraduate Bosowa University Publishing (PBUP)
Indonesian Journal of Business and Management
e-ISSN: $2460-3767 \quad p$-ISSN: $2656-6885$
Pttps://postgraduate.universitasbosowa.ac.id/index.php/jbm

\title{
HUBUNGAN GAYA KEPEMIMPINAN TRANFORMASIONAL DAN KOMUNIKASI INTERPERSONAL TERHADAP KINERJA KARYAWAN MELALUI KEPUASAN KERJA DI PT MALLOMO
}

\author{
The Relationship of Transformational Leadership Style and Interpersonal Communication to Employee \\ Performance Through Job Satisfaction at PT. Mallomo \\ Muhammad Subhan Kadir ${ }^{1}$, Thamrin Abduh ${ }^{2}$, Firman Menne ${ }^{2}$ \\ ${ }^{1}$ PT. Lobo Artha Pratama Kota Makassar \\ ${ }^{2}$ Program Studi Manajemen Program Pascasarjana Universitas Bosowa \\ Email: muhammadsubhan309@gmail.com
}

Diterima: 20 September 2021/Disetujui: 24 Desember 2021

\begin{abstract}
ABSTRAK
Penelitian ini bertujuan untuk mengkaji, menganalisis dan menginterprestasi Gaya Kepemimpinan Tranformasional dan Komunikasi Interpersonal Terhadap Kinerja Karyawan Melalui Kepuasan Kerja di PT. Mallomo. Penelitian ini bersifat deskriftip analisis dengan menggunakan metode penelitian kuantitatif. Data diperoleh dari PT. Mallomo dan responden (Karyawan PT. Mallomo). Hasil penelitian ini menemukan beberapa faktor yang mempengaruhi kinerja karyawan di PT. Mallomo. Antara lain gaya kepemimpinan tranformasional, komunikasi interpersonal dan kepuasan kerja berpengaruh positif dan signifikan terhadap kinerja karyawan di PT. Mallomo.Gaya Kepemimpinan Tranformasional berpengaruh positif dan signifikan terhadap kepuasan kerja. Komunikasi Interpersonal terhadap kepuasan kerja berpengaruh positif dan signifikan. Pengaruh kepuasan kerja berpengaruh positif dan signifikan terhadap kinerja karyawan di PT. Mallomo. Gaya Kepemimpinan Tranformasional berpengaruh positif dan signifikan terhadap kinerja karyawan melalui kepuasan kerja di PT. Mallomo. Komunikasi Interpersonal berpengaruh positif dan signifikan terhadap kinerja karyawan melalui kepuasan kerja di PT. Mallomo.
\end{abstract}

Kata Kunci: Gaya Kepemimpinan Tranformasional, Komunikasi Interpersonal, Kepuasan Kerja, Kinerja karyawan

\section{ABSTRACT}

This study aims to examine, analyze and interpret the Transformational Leadership Style and Interpersonal Communication on Employee Performance through Job Satisfaction at PT. Mallomo. This research is descriptive analysis using quantitative research methods. Data obtained from PT. Mallomo and respondents (Employees of PT. Mallomo). The results of this study found several factors that affect the performance of employees at PT. Mallomo. Among other things, transformational leadership style, interpersonal communication and job satisfaction have a positive and significant impact on employee performance at PT. Mallomo. Transformational Leadership Style has a positive and significant effect on job satisfaction. Interpersonal communication on job satisfaction has a positive and significant effect. The effect of job satisfaction has a positive and significant effect on employee performance at PT. Mallomo. Transformational Leadership Style has a positive and significant effect on employee performance through job satisfaction at PT. Mallomo. Interpersonal Communication has a positive and significant effect on employee performance through job satisfaction at PT. Mallomo.

Keywords: Transformational Leadership Style, Interpersonal Communication, Job Satisfaction And Employee Performance.

This work is licensed under Creative Commons Attribution License 4.0 CC-BY International license 


\section{PENDAHULUAN}

Keberhasilan sebuah perusahaan dalam melaksanakan persaingan dapat dilihat dari kondisi internal perussahaan tersebut, apa yang mereka terapkan, apa yang pemimpin mereka lakukan, dll dalam mewujudkan visi dan misi perusahaan. Secara umum, sebuah perusahaan didirikan dengan tujuan untuk mencapai visi yang sudah ditetapkan, salah satunya ialah memperoleh keuntungan dari hasil penjualan (produk/jasa) agar keberlangsungan hidup sebuah perusahaan tetap berjalan. Salah satu perusahaan swasta nasional yang sampai saat ini masih bertahan dan bahkan berkembang di tengah pusaran persaingan ialah Bosowa Corporation.

Keberhasilan tersebut menurut apa yang penulis sampaikan di atas bahwa kondisi internal perusahaan berjalan dengan baik, hubungan antara pemimpin - bawahan, dan hubungan antara sesama bawahan. Lebih spesifik lagi bahwa ada hal-hal yang dilakukan atau diterapkan oleh pemimpin kepada bawahannya agar baik pemimpin maupun bawahan dapat menghargai satu sama lain, hingga mampu melaksanakan tugasnya masing-masing secara baik.

Beberapa hal yang dimaksud oleh peneliti di atas antara lain adalah gaya kepemimpinan, gaya komunikasi, dan kepuasan kerja yang dapat tentunya berpengaruh terhadap kinerja karyawan. Hal tersebut bersifat internal, yaitu lingkup dalam perusahaan itu sendiri, hal-hal yang dapat menunjang keberhasilan sebuah perusahaan dalam mencapai visi dan misinya

Gaya kepemimpinan merupakan norma perilaku yang digunakan oleh seorang pemimpin untuk mempengaruhi perilaku orang lain seperti yang ia inginkan. Gaya kepemimpinan dapat dibagi menjadi dua tipe, yaitu gaya kepempinan transformasional dan gaya kepemimpinan transaksional. Gaya kepemimpinan transformasional menunjukan perilaku seorang pemimpin yang berorientasi pada proses membangun komitmen dan memberi kepercayaan kepada bawahan terhadap sasaran organisasi. sedangkan gaya kepemimpinan transaksional gaya ini menekankan transaksi di antara pemimpinan dan bawahan seperti transaksi berupa reward apabila bawahan mampu menyelesaikan tugasnya sesuai dengan kesepakatan yang telah dibuat scara bersama.

Dalam melaksanakan gaya kepemimpinan transformasional, hal mutlak yang perlu dilakukan seorang pemimpin terhadap bahawannya adalah komunikasi. Menurut Hardjana dalam Daryanto (2011), Salah satu jenis komunikasi yang frekuensi terjadinya cukup tinggi adalah komunikasi interpersonal atau komunikasi antarpribadi. Komunikasi antar pribadi ini menurut peneliti paling efektif dalam membangun hubungan emosional antara pemimpin dan bawahan. komunikasi interpersonal merupakan komunikasi antara orangorang secara tatap muka, yang memungkinkan setiap pesertanya menangkap reaksi orang lain secara langsung, baik secara verbal maupun nonverbal. Komunikasi interpersonal tidak hanya dengan apa yang dikatakan, yaitu bahasa yang digunakan, tapi bagaimana dikatakan misalnya non-verbal pesan yang dikirim, seperti nada suara dan ekspresi wajah. Adapun ciri-ciri komunikasi interpersonal ialah selektif, sistematis, unik, proses, transaksional, individual, pengetahuan personal, dan menciptakan makna.
Kedua hal di atas (Gaya kepimpinan Transformasional dan Komunikasi Interpersonal) menurut peneliti ialah hal yang membuat kinerja karyawan menjadi lebih baik dari sebelumnya hingga tercapainya kepuasan kerja oleh mereka. Dimana jika hal tersebut terjadi secara terus-menerus dan berkesinambungan, maka perusahaan dapat memaksimalkan potensinya dalam menghadapi persaingan.

Dalam penelitian ini, peneliti menggunakan metode penelitian kuantitatif. Mengingat bahwa dalam penelitian ini terdapat data dalam bentuk angka dan jumlah, dimana aspek numerik tersebut hanya dapat diproses melalui proses kuantitatif, bukan kualitatif. Penelitian kuantitatif ialah metode yang menekankan pada aspek matematis suatu gejala secara objektif terhadap sebuah fenomena sosial.

\section{METODE}

\section{a. Jenis Penelitian}

Penelitian 'kuantitatif untuk mengobservasi sampel dari populasi, penelitian kuantitatif ialah metode yang menekankan pada aspek matematis suatu gejala secara objektif terhadap sebuah fenomena sosial.

\section{b. Lokasi Penelitian}

Sasaran penelitianya itu karyawan yang saat ini bekerja di PT. Mallomo. Lokasi penelitian di dasarkan atas pertimbangan bahwa data yang dipergunakan oleh peneliti untuk menjawab masalah dalam penelitian ini memungkinkan diperoleh di PT. Mallomo. Masa pada penelitian ini dilakukan selarna 2 bulan.

\section{c. Populasi dan Sampel}

Populasi merupakan banyaknya kelengkapan pada bagian sasaran analisa yang ciri-ciri karakteristik ingin diduga. Populasi pada penelitian ini merupakan karyawan di PT. Mallomo.

Sampel merupakan komponen yang didapat dari sebuah populasi yang diteliti, pengambilan sampel menerapkan metode Purposive Sampling pada karyawan dan menerapkan rumus slovin, maka didapatkan sebanyak 73 sampel yang akan diteliti. Penelitian ini memakai sampel jenuh atau full sampling, yang berarti bahwa semua populasi menjadi sampel penelitian.

\section{d. Variabel Penelitian}

Terdapat 4 variable penelitian yang terdiriatas $2^{\circ}$ vanabel' exogen, 1' vanabe 'l intervening', dan' 1 variiabel' endogen, dimana setiap variable memiliki indicator sebagai berikut:

1. Variabel Exogen

a. Gaya KepemimpinanTranformasional

Indikator:

1. Karisma pemimpin;

2. Motivasi insparatif;

3. Simultasi intelektual; dan

4. Perhatian yang individual.

b. Komunikasi Interpersonal

Indikator;

1. Bahasa tubuh;

2. Kondisi;

3. Lingkungan fisik;

4. Lingkungan sosial;

5. Citra pihak lain; dan 
6. Citra diri.

2. Variabel Intervening

Indikator:

1. Lingkunga'n kerja;

2. Manajemen;

3. Isi pekerjaan;

4. Promosi ke'rja;

5. Pelatihan kerja; dan

6. Kompensasi.

3. Variabel Endogen

a. Kinerja karyawan

Indikator:

1. Kuantitas;

2. Kualitas;

3. Komunikasi;

4. Sikap; dan

5. Kerjasama.

\section{e. Teknik Pengumpulan Data}

Kuesioner adalah susunan beberapa pertanyaan untuk mendapatkan data dalam bentuk tanggapan responden yang terkait dengan penelitian. Kuesioner sebagai salah satu cara mengumpulkan data yang disusun secara terstuktur, sehingga nantinya mendapatkan data yang akurat. Sani dan Maharani (2013) mengemukakan pendapatnya bahwa kuesioner ialah cara mendapatkan data yang efektif. Pada penelitian ini penulis akan membagikan kuesioner kepada sampel (responden) untuk diisi secara langsung oleh mereka.

Teknik pengumpulan data yang berikutnya ialah metode wawancara, dilakukan dengan mewawancarai responden secara langsung (tatap muka), khususnya karyawan P.T. Mallomo. Terdiri atas lokasi, kinerja dari karyawan, serta data-data lain untuk mendapatkan informasi yang diperlukan.

Metode terakhir adalah dokumentasi, ditempuh dengan cara perekaman suara pada saat proses wawancara berlangsung, pengambilan video dan/atau gambar yang terkait dengan penelitian ini. Adapun hal yang dapat didokumentasikan dalam penelitian ini sebagaimana yang dinyatakan oleh Sani dan Masyhuri (2010).

\section{f. Jenis dan Sumber Data}

Data primer ialah data ya'ng didapatkan dan yang diku,mpulkan se,cara langs,ung dari hasil wawancara karyawan P.T. Mallomo. Sedangkan data sekunder ialah data didapatkan secara tidak langsung, seperti hasil field note (catatan data tambahan selama proses pengumpulan data primer dilakukan) dapat berupa kondisi eksisting, temuan lapangan, ataupun arsip-arsip yang dipublikasikan.

\section{g. Teknis Analisis Data}

Analisis data ialah cara memproses data dikumpulkan dari semua responden. Analisi,s jal,ur dipergunakan dalam analisis pol,a huburigan antara variable, tujuannya ialah unt,uk mengetahui adakah pengaruh langsung maupun tak langsung pada seperangkat variable bebas, yaitu exogen dengan var,iabel endog,en.

1. Uji T (T-tes)

Dalam Uji T Sarwono (2007) menyatakan bahwa uji T ini digunakan dalam membuktikan signifikasi variable exogen dengan variable endogen secara individu dengan kepercayaan 95\% dan kesalahan 5\%. apabila t hitung maka terdapat pengaruh variable exogen dan endogen, demikian pula sebaliknya. Ji,ka, $\mathrm{t}<0,05$ $\mathrm{m}$,aka ada peg,ar,uh variable exogen da, $\mathrm{n}$ endogen demi,kian j,uga sebaliknya.

2. Uji F

Uji F menurut Sarwono (2007) pada dasarnya ialah indikator yang dapat menunjukkan dimana seluruh variable exogen yang termasuk model terdapat pengaruh simultan dengan variabel endogen. Perbandingan $\mathrm{F}$ hitung $>\mathrm{F}$ table akan dapat diketahui pengaruh darivariabel exogen dan endogen demikian sebaliknya, jika $\mathrm{F}<5 \%$ maka pengaruh dari variable exogen maupun endogen dan sebaliknya.

3. Nilai Koefisien Deterrninasi (R2)

Apabila model dari regresi digunakan dan diperkirakan, makin tinggi nilai $\mathrm{R} 2$ naka rnakin besar kekua,tan d,ari persarnaan regresi, dengan dernikian di prediksi dari var,abel kriterion sernakin baik. Sani dan Maharani (2013).

4. Analisis Jalur

Adapun pemodelan ini digunakan untuk meng,etahui pen,garuh yang langsung maupun tidak langsung, dan variabel yang mempengaruhi (exogen) ter,hadap variable dipengaruhi (endogen).

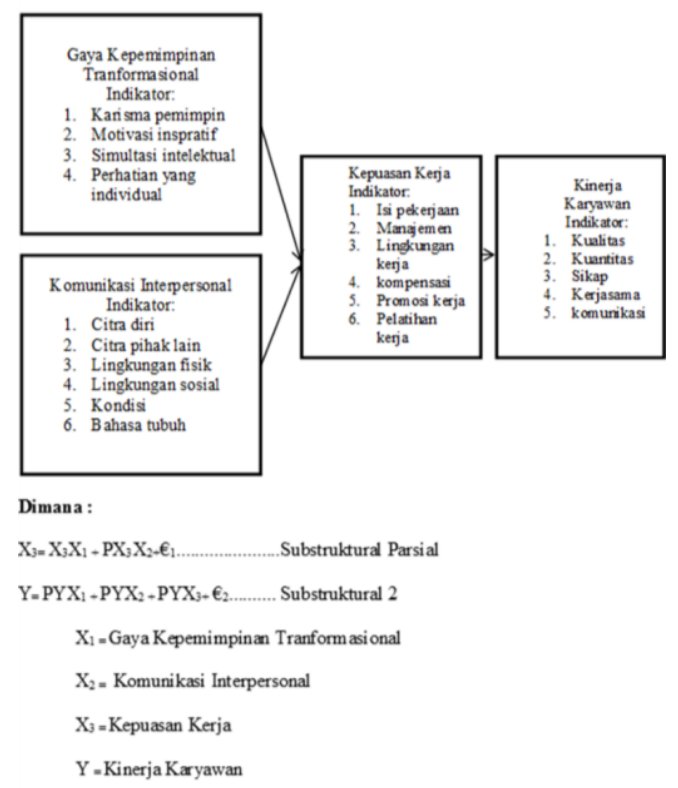

\section{HASIL DAN PEMBAHASAN}

\section{a. Gaya Kepemimpinan Transformasional}

Berdasarkan dari tanggapan ressponden mengenai Gaya Kepemimpinan Tranformasional (X1), sebagian besar respo,nden memberikan jawaban sangat setuju dengan ratarata $33,83 \%$. Hal ini dapat dilihat pada setiap indikator pertanyaan yang disajikan mengenai Karisma Pemimpin, Motivasi Insparatif, Simulasi Intelektual, dan Perhatian yang Individual. 
Tabel 1. Presepsi Responden terhadap Variabel Gaya Kepemimpinan Tranformasional

\begin{tabular}{|c|c|c|c|c|c|c|c|}
\hline \multirow{2}{*}{ No } & \multirow{2}{*}{ Indikator } & \multicolumn{5}{|c|}{ Jawaban } & \multirow[b]{2}{*}{ Jumlah } \\
\hline & & SS (5) & S (4) & $\mathrm{N}(3)$ & TS (2) & STS (1) & \\
\hline \multicolumn{8}{|c|}{ Gaya Kepemimpinan Tranformasional $\left(\mathrm{X}_{1}\right)$} \\
\hline \multirow{2}{*}{1} & GKT1 & 43 & 27 & 3 & \multirow[b]{2}{*}{-} & \multirow[b]{2}{*}{ - } & 73 \\
\hline & & $58,90 \%$ & $37 \%$ & $4,10 \%$ & & & $100 \%$ \\
\hline \multirow{2}{*}{2} & \multirow{2}{*}{ GKT2 } & 41 & 31 & 1 & \multirow[b]{2}{*}{ - } & \multirow[b]{2}{*}{ - } & 73 \\
\hline & & $56,16 \%$ & $42,46 \%$ & $1,36 \%$ & & & $100 \%$ \\
\hline \multirow{2}{*}{3} & \multirow{2}{*}{ GKT3 } & 39 & 33 & 1 & \multirow[b]{2}{*}{$\ldots$} & \multirow[b]{2}{*}{-} & 73 \\
\hline & & $53,42 \%$ & $45,20 \%$ & $1,36 \%$ & & & $100 \%$ \\
\hline \multirow{2}{*}{4} & \multirow{2}{*}{ GKT4 } & 19 & 53 & 1 & \multirow[b]{2}{*}{ - } & \multirow[b]{2}{*}{ - } & 73 \\
\hline & & $26,02 \%$ & $72,60 \%$ & $1,36 \%$ & & & $100 \%$ \\
\hline \multirow{2}{*}{5} & \multirow{2}{*}{ GKT5 } & 20 & 46 & 7 & \multirow{2}{*}{ - } & \multirow{2}{*}{ - } & 73 \\
\hline & & $27,39 \%$ & $63,01 \%$ & $9,58 \%$ & & & $100 \%$ \\
\hline \multirow{2}{*}{6} & \multirow{2}{*}{ GKT6 } & 12 & 27 & 23 & 11 & \multirow[b]{2}{*}{-} & 73 \\
\hline & & $16,43 \%$ & $37 \%$ & $31,50 \%$ & $15,06 \%$ & & $100 \%$ \\
\hline \multirow{2}{*}{7} & \multirow{2}{*}{ GKT7 } & 28 & 43 & 2 & \multirow[t]{2}{*}{ then } & & 73 \\
\hline & & $36,35 \%$ & $59 \%$ & $2,73 \%$ & & & $100 \%$ \\
\hline & & 26 & 35 & 9 & 2 & 1 & 73 \\
\hline 8 & GKT8 & $31,61 \%$ & $48 \%$ & $12,32 \%$ & $2,73 \%$ & $1,36 \%$ & $100 \%$ \\
\hline & & 14 & 26 & 28 & 5 & & 73 \\
\hline 9 & GKT9 & $19,17 \%$ & $31,61 \%$ & $36,35 \%$ & $6,84 \%$ & - & $100 \%$ \\
\hline 10 & GKT10 & 6 & 15 & 19 & 24 & 9 & 73 \\
\hline 10 & जК 1 & $8,21 \%$ & $20,54 \%$ & $26,02 \%$ & $32,87 \%$ & $12,32 \%$ & $100 \%$ \\
\hline & GKT 11 & 8 & 35 & 30 & 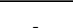 & 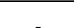 & 73 \\
\hline 11 & GKTII & $10,95 \%$ & $48 \%$ & $41,09 \%$ & - & - & $100 \%$ \\
\hline & GKT12 & 6 & 35 & 32 & & & 73 \\
\hline 12 & GK 112 & $8,21 \%$ & $48 \%$ & $43,85 \%$ & - & - & $100 \%$ \\
\hline & ata-rata & $21,83 \%$ & $33,83 \%$ & $13 \%$ & $10,5 \%$ & $5 \%$ & $100 \%$ \\
\hline
\end{tabular}

1) Karisma Pemimpin

Pada item pertanyaan pertama, terdapat 43 oran,g respontden yang memlih opsi jawa,ban 'sangat setuju', pada profit jawaban sebesar 56,16\%. Opsi jawaban 'setuju' terdapat sebanyak 31 orang, dengan persentase jawaban sebesar 42,46\%. Opsi jawaban 'netral' sebanyak 3 orang dengan persentase $4,10 \%$. Pada item pertanyaan kedua, terdapat 41 orang responden yang memlih 'san,gat setuju', dengan profit jawaban sebesar 58,90\%. Opsi jawaban 'setuju' terdapat sebanyak 27 orang yang memilih, dengan persentase jawaban sebesar 37\%, dan untuk jawaban 'netral' yaitu sebanyak 1 orang pada profit $1,36 \%$. Pada item pertanyaan ketiga, terdapat 39 res,ponden yang memlih opsi jaw,abann 'san,gat 'setuju', pada profit jawaban sebesar 53,42\%. Opsi jawaban 'setuju' terdapat sebanyak 33 orang yang memilih, dengan persentase jawaban sebesar $45,20 \%$, dan untuk jawaban 'netral' yaitu sebanyak 1 orang pada profit $1,36 \%$.

\section{2) Motivasi Inspiratif}

Pada item pertanyaan keempat, opsi jawaban 'setuju' terdapat sebanyak 53 orang responden yang memlih jawaban tersebut, pada profit jawaban sebesar 73,60\%. Opsi jawaban 'sangat setuju' terdapat 19orang yang memilih, dengan persentase sebesar 27,39\%, dan untuk jawaban 'netral' yaitu sebanyak 1 orang pada profit sebesar $1,36 \%$. Pada item pertanyaan kelima, opsi jawaban 'setuju' terdapat sebanyak 46 orang responden yang memlih, pada profit jawaban sebesar $63,01 \%$. Opsi jawaban 'sangat setuju' terdapat 20 orang yang memilih, dengan persentase jawaban $27,39 \%$, dan untuk jawaban 'netral' yaitu sebanyak 7 orang pada profit sebesar 9,58\%. Pada item pertanyaan keenam, opsi jawaban 'setuju', terdapat 27 orang responden yang memlih pada profit jawaban sebesar $37 \%$. Opsi jawaban 'netral' terdapat sebanyak 23orang dengan persentase jawaban sebesar $31,50 \%$, dan untuk jawaban 'tidak setuju' yaitu sebanyak 11 orang pada profit sebesar $15,60 \%$.

\section{3) Simulasi Intelektual}

Pada item pertanyaan ketujuh, opsi jawaban 'setuju', terdapat sebanyak 43 orang responden yang memlih pada profit jawaban sebesar 59\%. Opsi jawaban 'sangat setuju' terdapat 28 orang yang memilih dengan persentase jawaban36,35\%, dan untuk jawaban 'netral' yaitu 2 orang pada profit $2,37 \%$. Pada item pertanyaan kedelapan, opsi jawaban 'setuju' terdapat 35 orang responden yang memlih pada profit jawaban sebesar $48 \%$. Opsi jawaban 'sangat setuju' terdapat 26 orang dengan persentase jawaban $31,61 \%$. Jawaban 'netral' yaitu sebanyak 9 orang pada profit sebesar $12,32 \%$, dan untuk jawaban 'tidak setuju' yaitu sebanyak 9 orang pada profit sebesar 2,37\%. Pada item pertanyaan kesembilan, opsi jawaban 'netral' terdapat sebanyak 28 orang responden yang memlih pada profit jawaban sebesar 36,35\%. Opsi jawaban 'setuju' terdapat sebanyak 26 orang dengan persentase jawaban sebesar 31,61\%.Jawaban 'sangat setuju' yaitu sebanyak 14 orang pada profit sebesar19,17\%, dan untuk jawaban 'tidak setuju' yaitu 5 orang responden pada profit $6,84 \%$.

4) Perhatian Yang Individual

Pada item pertanyaan kesepuluh, opsi jawaban 'tidak setuju' terdapat 24 orang responden yang memlih pada profit jawaban sebesar 32,87\%. Opsi jawaban 'netral' terdapat 19 orang dengan persentase jawaban sebesar $26,02 \%$. Jawaban 'setuju' yaitu 15 orang responden pada profit 20,54\%. Jawaban 'sangat tidak setuju' yaitu 9 orang responden pada profit $12,32 \%$, dan untuk opsi jawaban 'sangat setuju' yaitu 6 orang responden pada profit $8,12 \%$. Pada item pertanyaan kesebelas, opsi jawaban 'setuju', terdapat sebanyak 35 orang responden yang memlih pada profit jawaban sebesar 48\%. Opsi jawaban 'netral' terdapat sebanyak 30 orang dengan persentase jawaban 41,09\%. Jawaban 'sangat setuju' yaitu sebanyak 8 orang responden pada profit $10,95 \%$. Pada item pertanyaan keduabelas, opsi jwaban 'setuju' terdapat 35 responde,n yang memlih pada profit jawaban sebesar 48\%. Opsi jawaban 'netral' terdapat 32 orang yang memilih dengan persentase jawaban sebesar $43,85 \%$. Jawaban 'sangat setuju' yaitu 6 orang responden pada profit $8,21 \%$.

\section{b. Komunikasi Interpersonal}

Berdasarkan dari tanggapan responden mengenai Komunikasi Interpersonal (X2), sebagian besar orang responden memberikan jawaban setuju dengan rata-rata $31,16 \%$. Hal ini dapat dilihat pada setiap indikator pertanyaan yang disajikan dengan jawaban orang responden sebagaimana penjelasan di bawah ini. 
Tabel 2. Presepsi Responden Terahdap Komunikasi Interpersonal

\begin{tabular}{|c|c|c|c|c|c|c|c|}
\hline \multirow{2}{*}{ No. } & \multirow{2}{*}{ Indikator } & \multicolumn{5}{|c|}{ Jawaban } & \multirow{2}{*}{ Jumlah } \\
\hline & & SS (5) & S (4) & $\mathrm{N}(3)$ & TS (2) & $\begin{array}{c}\text { STS } \\
(1)\end{array}$ & \\
\hline \multicolumn{8}{|c|}{ Komunikasi Interpersonal $\left(\mathrm{X}_{2}\right)$} \\
\hline 1 & KI 1 & $\begin{array}{c}27 \\
37 \% \\
\end{array}$ & $\begin{array}{c}38 \\
51,05 \% \\
\end{array}$ & $\begin{array}{c}8 \\
11 \% \\
\end{array}$ & - & - & $\begin{array}{c}73 \\
100 \% \\
\end{array}$ \\
\hline 2 & KI 2 & $\begin{array}{c}35 \\
34,24 \%\end{array}$ & $\begin{array}{c}39 \\
53,42 \%\end{array}$ & $\begin{array}{c}9 \\
12,32 \%\end{array}$ & - & - & $\begin{array}{c}73 \\
100 \%\end{array}$ \\
\hline 3 & KI 3 & $\begin{array}{c}25 \\
34,24 \%\end{array}$ & $\begin{array}{c}42 \\
57,535\end{array}$ & $\begin{array}{c}6 \\
8,21 \%\end{array}$ & - & - & $\begin{array}{c}73 \\
100 \%\end{array}$ \\
\hline 4 & KI 4 & $\begin{array}{c}25 \\
34,24 \%\end{array}$ & $\begin{array}{c}38 \\
52,05 \%\end{array}$ & $\begin{array}{c}10 \\
13,69 \%\end{array}$ & - & - & $\begin{array}{c}73 \\
100 \%\end{array}$ \\
\hline 5 & KI 5 & $\begin{array}{c}22 \\
30,13 \%\end{array}$ & $\begin{array}{c}44 \\
60,27 \%\end{array}$ & $\begin{array}{c}7 \\
9,58 \%\end{array}$ & - & - & $\begin{array}{c}73 \\
100 \%\end{array}$ \\
\hline 6 & KI 6 & $\begin{array}{c}24 \\
32,87 \%\end{array}$ & $\begin{array}{c}45 \\
61,64 \%\end{array}$ & $\begin{array}{c}4 \\
5,47 \%\end{array}$ & - & - & $\begin{array}{c}73 \\
100 \%\end{array}$ \\
\hline 7 & KI 7 & $\begin{array}{c}29 \\
39,72 \%\end{array}$ & $\begin{array}{c}38 \\
52,05 \%\end{array}$ & $\begin{array}{c}6 \\
8,21 \%\end{array}$ & - & - & $\begin{array}{c}73 \\
100 \%\end{array}$ \\
\hline 8 & KI 8 & $\begin{array}{c}8 \\
11 \%\end{array}$ & $\begin{array}{c}21 \\
28,76 \%\end{array}$ & $\begin{array}{c}22 \\
30,13 \%\end{array}$ & $\begin{array}{c}18 \\
24,65 \%\end{array}$ & $\begin{array}{c}4 \\
5,47 \%\end{array}$ & $\begin{array}{c}73 \\
100 \%\end{array}$ \\
\hline 9 & KI 9 & $\begin{array}{c}3 \\
4,10 \%\end{array}$ & $\begin{array}{c}19 \\
26,02 \%\end{array}$ & $\begin{array}{c}46 \\
63,01 \%\end{array}$ & $\begin{array}{c}5 \\
6,84 \%\end{array}$ & - & $\begin{array}{c}73 \\
100 \%\end{array}$ \\
\hline 10 & KI 10 & $\begin{array}{c}3 \\
4,10 \%\end{array}$ & $\begin{array}{c}17 \\
23,28 \%\end{array}$ & $\begin{array}{c}38 \\
52,05 \%\end{array}$ & $\begin{array}{c}12 \\
16,43 \%\end{array}$ & $\begin{array}{c}3 \\
4,10 \%\end{array}$ & $\begin{array}{c}73 \\
100 \%\end{array}$ \\
\hline 11 & KI 11 & $\begin{array}{c}6 \\
8,21 \%\end{array}$ & $\begin{array}{c}17 \\
23,28 \%\end{array}$ & $\begin{array}{c}26 \\
35,61 \%\end{array}$ & $\begin{array}{c}20 \\
27,39 \%\end{array}$ & $\begin{array}{c}4 \\
5,47 \%\end{array}$ & $\begin{array}{c}73 \\
100 \%\end{array}$ \\
\hline 12 & KI 12 & $\begin{array}{c}7 \\
9,58 \%\end{array}$ & $\begin{array}{c}16 \\
21,91 \%\end{array}$ & $\begin{array}{c}26 \\
35,61 \%\end{array}$ & $\begin{array}{c}19 \\
26,02 \%\end{array}$ & $\begin{array}{c}5 \\
6,84 \%\end{array}$ & $\begin{array}{c}73 \\
100 \%\end{array}$ \\
\hline & a-rata & $17 \%$ & $31,16 \%$ & $17,33 \%$ & $14,8 \%$ & $4 \%$ & $100 \%$ \\
\hline
\end{tabular}

1) Citra Diri

Pada item pertanyaan pertama, sebanyak 38 orang memilih jawaban 'setuju' pada profit jawaban sebesar 51, $05 \%$. Jawaban 'sangat setuju' terdapat 27 orang pada profit jawaban sebesar 37\%. Jawaban 'netral' sebanyak 8 orang pada profit $11 \%$. Pada item pertanyaan kedua, sebanyak 39 orang yang memilih jawaban'setuju' pada profit jawaban sebesar 34,24\%. Jawaban 'netral' yaitu 9 orang pada persentase $12,32 \%$.

2) Citra Pihak Lain

Pada item pertanyaan ketiga sebanyak 42 orang yang memilih jawaban'setuju' pada profit jawaban sebesar $57,53 \%$. Jawaban 'sangat setuju' dipilih 25 orang pada profit jawaban 34,24\%. Jawaban 'netral' sebanyak 6 orang dengan persentase jawaban $8,21 \%$. Pada item pertanyaan keempat sebanyak 38 orang yang memilih jawaban'setuju' pada profit jawaban $52,05 \%$. Jawaban 'sangat setuju' yaitu 25 orang pada profit jawaban 34,24\%. Jawaban 'netral'10 orang dengan persentase jawaban sebesar 13,69\%.

\section{3) Lingkungan Fisik}

Pada item pertanyaan kelima sebanyak 44 orang yang memilih 'setuju' pada profit jawaban 60,27\%. Jawaban 'sangat setuju' sebanyak 22 orang pada profit jawaban sebesar 30,13\%. Jawaban 'netral' 7 orang pada profit jawaban 9,58\%. Pada item pertanyaan keenam sebanyak 45 orang yang memilih 'setuju' pada profit jawaban sebesar $61,64 \%$. Jawaban 'sangat setuju' sebanyak 24 orang pada profit jawaban $32,87 \%$. Jawaban 'netral' sebanyak 4 orang pada persentase jawaban $5,47 \%$.

4) Lingkungan Sosial

Pada item pertanyaan ketujuh sebanyak 38 orang yang memilih 'setuju' pada profit jawaban 52,05\%. Jawaban 'sangat setuju' 29 orang pada profit jawaban 39,72\%. Jawaban 'netral' sebanyak 6 orang pada persentase 8,21\%. Pada item pertanyaan kedelapan sebanyak 22 orang yang memilih 'netral' pada profit jawaban sebesar 30,13\%. Jawaban 'setuju' sebanyak 21 orang pada profit jawaban sebesar 28,76\%. Jawaban 'tidak setuju' 18 orang pada profit jawaban sebesar 24,65\%. Jawaban 'sangat setuju' 8 orang pada profit jawaban sebesar 11\%. Jawaban 'sangat tidak setuju' 4 orang dalam persentae jawaban sebesar $5,47 \%$.

\section{5) Kondisi}

Pada item pertanyaan kesembilan sebanyak 46 orang yang memilih 'netral' pada profit jawaban sebesar $63,01 \%$. Jawaban 'setuju' 19 orang pada profit jawaban $26,02 \%$. Jawaban 'tidak setuju' 5 orang pada profit jawaban sebesar $6,84 \%$. Jawaban 'sangat setuju' 3 orang pada profit jawaban sebesar 4,10\%. Pada item pertanyaan kesepuluh sebanyak 38 orang yang memilih 'netral' dengan persentase jawaban sebesar 52,05\%. Jawaban 'setuju' 17 orang pada profit jawaban 23,28\%. Jawaban 'tidak setuju' 12 orang pada profit jawaban sebesar 16,43\%. Jawaban 'sangat setuju' 3 orang dalam profit jawaban $4,10 \%$, dan untuk opsi jawaban 'sangat tidak setuju' terdapat 3 orang pada persentase jawaban $4,10 \%$.

\section{6) Bahasa Tubuh}

Pada item pertanyaan kesebelas sebanyak 26 orang yang memilih 'netral' dengan persentase jawaban 35,61\%. Opsi jawaban 'tidak setuju' terdapat 20 orang pada persentase jawaban sebesar 27,39\%, untuk jawaban 'setuju' 17 orang pada persentase jawaban 23,28\%. Jawaban 'sangat setuju' 6 orang pada persentase jawaban sebesar $8,21 \%$,untuk opsi jawaban 'sangat tidak setuju' 4 orang pada persentase jawaban sebesar 5,47\%. Pada item pertanyaan keduabelas sebanyak 26 orang yang memilih 'netral' dengan persentase jawaban sebesar 35,61\%. Jawaban 'tidak setuju' 19 orang pada persentase jawaban $26,02 \%$, untuk jawaban 'setuju' sebanyak 16 orang pada persentase jawaban sebesar 21,91\%. Opsi jawaban 'sangat setuju' 7 orang dengan persentase jawaban 9,58\%, sedangkan opsi jawaban 'sangat tidak setuju' 5 orang dengan profit $6,84 \%$.

\section{c. Kepuasan Kerja}

Hasil dari tanggapan responden mengenai kepuasan kerja (X3), sebagian besar responden meberikan jawaban setuju dengan rata $37,30 \%$. Hal ini dapat dilihat pada setiap indikator pertanyaan yang disajikan mengenai is, pekrejaan, komp,ensasi, ling,kungan kerja, manaejmen, promo,si kerja dan pela,tihan kerja dengan penjelasan sperti dibawah ini. 
Hubungan Gaya Kepemimpinan Tranformasional dan..... (Muhammad Subhan Kadir, Thamrin Abduh, Firman Menne)

Tabel 3. Presepsi Rseponden Terhadap Kepuasan K,erja

\begin{tabular}{|c|c|c|c|c|c|c|c|}
\hline \multirow{2}{*}{ No. } & \multirow{2}{*}{ Indikator } & \multicolumn{5}{|c|}{ Jawaban } & \multirow{2}{*}{ Jumlah } \\
\hline & & SS (5) & S (4) & $\mathrm{N}(3)$ & TS (2) & STS (1) & \\
\hline \multicolumn{8}{|c|}{ Kepuasan Kerja $\left(\mathrm{X}_{3}\right)$} \\
\hline \multirow{2}{*}{1} & KK 1 & 13 & 46 & 14 & \multirow[b]{2}{*}{ - } & \multirow[t]{2}{*}{ - } & 73 \\
\hline & & $17,80 \%$ & $63,01 \%$ & $19,17 \%$ & & & $100 \%$ \\
\hline \multirow{2}{*}{2} & KK 2 & 17 & 52 & 4 & \multirow[b]{2}{*}{$\begin{array}{ll}- & -1 \\
-1\end{array}$} & \multirow[b]{2}{*}{ - } & 73 \\
\hline & KK 2 & $23,18 \%$ & $71,23 \%$ & $5,47 \%$ & & & $100 \%$ \\
\hline \multirow{2}{*}{3} & & 20 & 43 & 10 & \multirow[b]{2}{*}{ - } & \multirow[b]{2}{*}{ - } & 73 \\
\hline & KK3 & $27,39 \%$ & $58,90 \%$ & $13,69 \%$ & & & $100 \%$ \\
\hline \multirow{2}{*}{4} & & 24 & 37 & 12 & \multirow[b]{2}{*}{ - } & \multirow[b]{2}{*}{ - } & 73 \\
\hline & KK 4 & $32,87 \%$ & $50,68 \%$ & $16,43 \%$ & & & $100 \%$ \\
\hline \multirow{2}{*}{5} & & 33 & 27 & 12 & 1 & \multirow[b]{2}{*}{ - } & 73 \\
\hline & KK 5 & $45,20 \%$ & $37 \%$ & $16,43 \%$ & $1,36 \%$ & & $100 \%$ \\
\hline \multirow{2}{*}{6} & & 27 & 27 & 17 & 2 & \multirow[b]{2}{*}{-} & 73 \\
\hline & КК 6 & $37 \%$ & $37 \%$ & $23,18 \%$ & $2,73 \%$ & & $100 \%$ \\
\hline \multirow{2}{*}{7} & & 32 & 24 & 16 & 1 & \multirow[b]{2}{*}{-} & 73 \\
\hline & KK 7 & $43,83 \%$ & $32,87 \%$ & $21,91 \%$ & $1,36 \%$ & & $100 \%$ \\
\hline \multirow{2}{*}{8} & & 29 & 29 & 15 & \multirow{2}{*}{ 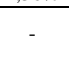 } & \multirow[t]{2}{*}{-} & 73 \\
\hline & KK 8 & $39,72 \%$ & $39,72 \%$ & $20,54 \%$ & & & $100 \%$ \\
\hline \multirow{2}{*}{9} & & 25 & 41 & 6 & 1 & \multirow[b]{2}{*}{ - } & 73 \\
\hline & KK 9 & $34,24 \%$ & $56,16 \%$ & $8,21 \%$ & $1,36 \%$ & & $100 \%$ \\
\hline \multirow{2}{*}{10} & & 23 & 38 & 12 & \multirow[t]{2}{*}{, } & & 73 \\
\hline & KK 10 & $31,50 \%$ & $52,05 \%$ & $16,43 \%$ & & - & $100 \%$ \\
\hline & & 29 & 36 & 7 & 1 & & 73 \\
\hline 11 & KK 11 & $39,72 \%$ & $49,31 \%$ & $9,58 \%$ & $1,36 \%$ & - & $100 \%$ \\
\hline 12 & KK 12 & 18 & 41 & 13 & 1 & & 73 \\
\hline 12 & KK 12 & $24,65 \%$ & $56,16 \%$ & $17,80 \%$ & $1,36 \%$ & - & $100 \%$ \\
\hline & & 17 & 44 & 11 & 1 & & 73 \\
\hline 13 & KK 13 & $23,18 \%$ & $60,27 \%$ & $15,06 \%$ & $1,36 \%$ & - & $100 \%$ \\
\hline & ta-rata & $23,61 \%$ & $37,30 \%$ & $11,46 \%$ & $1,16 \%$ & $\%$ & $100 \%$ \\
\hline
\end{tabular}

1) Isi Pekerjaan

Pada item pertanyaan pertama sebanyak 46 orang memilih 'setuju' pada profit jawaban sebesar 63,01\%. Jawaban 'netral' sebanyak 14 orang pada profit jawaban sebesar $19,17 \%$. Jawaban 'sangat setuju' sebanyak 13 orang pada profit jawaban sebesar $17,80 \%$. Pada item pertanyaan pertama sebanyak 53 orang y,ang menjawab 'setuju' pada profit jawaban sebesar $71,23 \%$. Jawaban 'sangat setuju' 17 orang pada profit jawaban $23,18 \%$. Jawaban 'netral' 4 orang pada profit jawaban 5,47\%.

2) Manajemen

Pada item pertanyaan ketiga seba,nyak 43 orang menjawab 'setuju' pada profit jawaban sebesar 58,90\%. Jawaban 'sangat setuju' 20 orang pada profit jawaban sebesar $27,39 \%$. Jawaban 'netral' sebanyak 10 orang pada profit jawaban sebesar 13,69\%. Pada item pertanyaan keempat sebanyak 37 orang menjawab 'setuju' pada profit jawaban sebesar 50,68\%. Jawaban 'sangat setuju' 24 orang pada profit jawaban 32,8\%. Jawaban 'netral' 12 orang dengan persentase jawaban sebesar $16,43 \%$.

\section{3) Lingkungan Kerja}

Pada item pertanyaan kelima sebanyak 33 orang menjawab 'sangat setuju' pada profit jawaban sebesar $45,20 \%$. Jawaban 'setuju' sebanyak 27 orang pada profit jawaban sebesar 37\%. Jawaban 'netral' sebanyak 12 orang pada profit jawaban 16,43\%. Opsi jawaban 'tidak setuju'1 orang dalam persentase $1,36 \%$. Pada item pertanyaan keenam sebanyak 27 orang menjawab 'sangat setuju' pada profit jawaban sebesar 37\%. Opsi jawaban 'setuju' 27 orang dengan persentase jawaban $37 \%$. Jawaban 'netral' sebanyak 17 orang dengan persentase jawaban $23,18 \%$. Opsi jawaban 'tidak' setuju terdapat 2 orang pada profit jawaban $2,73 \%$.

\section{4) Kompensasi}

Pada item pertanyaan ketujuh sebaynak 32 orang menjawab 'sangat setuju' pada profit jawaban sebesar $43,83 \%$. Opsi jawaban 'setuju' sebanyak 24 orang pada profit jawaban sebesar 32,87\%. Jawaban 'netral' sebanyak 16 orang pada profit jawaban sebesar 21,91\%. Opsi jawaban tida,k set,uju sebaynak 1 or,ang dengan persentase jawa,ban sebesar 1,36\%. Pada item pertanyaan kedelapan seba,nyak 29 orang menja,wab 'sangat setuju' pada profit jawaban sebesar 39,72\%. Jawaban 'setuju' 29 orang pada profit jawaban 39,27\%. Jawaban 'netral' sebanyak 15 orang pada profit jawaban sebesar $20,54 \%$.

5) Promosi Kerja

Pada item pertanyaan kesembilan terdapat 41 orang memilih 'setuju' pada profit jawaban 56,16\%. Jawaban 'sangat setuju'25 orang pada profit jawaban 34,24\%. Jawaban 'netral' 6 orang pada profit jawaban 8,21\%. Opsi jawaban 'tidak setuju' 1 orang pada persentase jawaban sebesar 1,36\%. Pada item pertanyaan kesepuluh sebayak 38 orang menjawab 'setuju' pada profit jawaban 52,05\%. Jawaban 'sangat setuju' 23 orang pada profit jawaban $31,50 \%$. Opsi jawaban 'netral' sebanyak 12 orang pada profit jawaban $16,43 \%$.

6) Pelatihan Kerja

Pada item pertanyaan kesebelas sebanyak 36 orang menjawab 'setuju' pada profit jawaban 49,31\%. Jawaban 'sangat setuju' 29 orang pada profit jawaban 39,72\%, untuk jawaban 'netral' sebanyak 7 orang pada profit jawaban sebesar 9,58\%. Opsi jawaban 'tidak setuju' 1 orang pada persentase jawaban sebesar $1,36 \%$. Pada item pertanyaan keduabelas seba,nyak 41 orang menjawab 'setuju' pada profit jawaban sebesar 56,16\%. Jawaban 'sangat setuju' sebanyak 18 orang pada profit jawaban 24,65\%. Jawaban 'netral'13 orang responden dengan persentase jawaban $17,80 \%$. Opsi jawaban 'tidak setuju' yaitu 1 orang dengan persentase jawaban $1,36 \%$. Pada item pertanyaan ketigabelas sebanak 44 orang me,njawab 'setuju' pada profit jawaban 60,27\%. Opsi jaw,aban 'sanga,t setuju' 17 orang resp,onden den,gan pres,entasi jaw,ab,an 23,18\%, untuk jawaban 'netral' 11 orang respondenpada profit jawaban sebesar 15,06\%. Opsi jawaban 'tidak setuju' 1 orang dengan persentase jawaban sebesar $1,36 \%$.

\section{d. Kinerja Karyawan}

Berdasarkan dari tanggapan orang responden mengenai kinerja karyawan (Y), kebanyakan orang responden menjawab setuju dengan rata-rata $38,11 \%$. Hal ini dapat dilihat pada setiap indikator pertanyaan yang disajikan mengenai kualitas, kuantitas, kerjasama dan komunikasi dengan jawaban orang responden seperti di bawah ini. 
Idn. J. of Business and Management, 4(1), Desember 2021, Halaman: 07-15, DOI: 10.35965/jbm.v4i1.1205

Tabel 4. Presepsi Responden Terhadap Kinerja Karyawan

\begin{tabular}{|c|c|c|c|c|c|c|c|}
\hline \multirow{2}{*}{ No. } & \multirow{2}{*}{ Indiikator } & \multicolumn{5}{|c|}{ Jawaban } & \multirow{2}{*}{ Jumlah } \\
\hline & & SS (5) & S (4) & $\mathrm{N}(3)$ & TS (2) & STS (1) & \\
\hline \multicolumn{8}{|c|}{ Kinerja Karyawan (Y) } \\
\hline \multirow{2}{*}{1} & KK 1 & 20 & 45 & 7 & 1 & 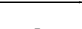 & 73 \\
\hline & & $27,39 \%$ & $61,64 \%$ & $9,58 \%$ & $1,36 \%$ & - & $100 \%$ \\
\hline \multirow{2}{*}{2} & & 20 & 42 & 10 & 1 & & 73 \\
\hline & KK 2 & $27,39 \%$ & $57,53 \%$ & $13,69 \%$ & $1,36 \%$ & - & $100 \%$ \\
\hline \multirow{2}{*}{3} & $K K_{3} 3$ & 18 & 44 & 8 & 3 & 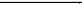 & 73 \\
\hline & KK 3 & $24,65 \%$ & $60,27 \%$ & $10,95 \%$ & $4,10 \%$ & - & $100 \%$ \\
\hline \multirow{2}{*}{4} & & 12 & 48 & 12 & 1 & & 73 \\
\hline & KK 4 & $16,43 \%$ & $65,75 \%$ & $16,43 \%$ & $1,36 \%$ & - & $100 \%$ \\
\hline \multirow{2}{*}{5} & KK 5 & 23 & 45 & 5 & 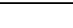 & & 73 \\
\hline & КК 5 & $31,50 \%$ & $61,64 \%$ & $6,84 \%$ & - & - & $100 \%$ \\
\hline \multirow[b]{2}{*}{6} & KK 6 & 26 & 34 & 13 & 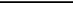 & 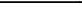 & 73 \\
\hline & КК 6 & $35,61 \%$ & $46,57 \%$ & $17,80 \%$ & - & - & $100 \%$ \\
\hline \multirow{2}{*}{7} & & 24 & 37 & 12 & & & 73 \\
\hline & KK 7 & $32,87 \%$ & $50,68 \%$ & $16,43 \%$ & - & - & $100 \%$ \\
\hline \multirow{2}{*}{8} & KK \& & 22 & 26 & 24 & 1 & & 73 \\
\hline & KK 8 & $30,13 \%$ & $35,61 \%$ & $32,87 \%$ & $1,36 \%$ & - & $100 \%$ \\
\hline \multirow{2}{*}{9} & $K K 0$ & 23 & 37 & 13 & 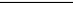 & 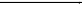 & 73 \\
\hline & КК 9 & $31,50 \%$ & $50,68 \%$ & $17,80 \%$ & - & - & $100 \%$ \\
\hline \multirow{2}{*}{10} & & 28 & 38 & 7 & 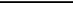 & 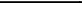 & 73 \\
\hline & KK 10 & $38,35 \%$ & $52,05 \%$ & $9,58 \%$ & - & - & $100 \%$ \\
\hline \multirow{2}{*}{11} & KK 11 & 32 & 40 & 1 & 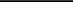 & & 73 \\
\hline & KK II & 48,83 & $54,79 \%$ & $1,36 \%$ & - & - & $100 \%$ \\
\hline \multirow{2}{*}{12} & & 32 & 37 & 3 & 1 & 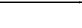 & 73 \\
\hline & KK 12 & $48,83 \%$ & $50,68 \%$ & $4,10 \%$ & $1,36 \%$ & - & $100 \%$ \\
\hline \multirow{2}{*}{13} & & 31 & 37 & 5 & & & 73 \\
\hline & KK 13 & $42,46 \%$ & $50,68 \%$ & $6,84 \%$ & - & - & $100 \%$ \\
\hline \multirow{2}{*}{14} & & 30 & 39 & 4 & 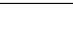 & 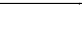 & 73 \\
\hline & KK 14 & $41,09 \%$ & $53,42 \%$ & $5,47 \%$ & - & - & $100 \%$ \\
\hline \multirow{2}{*}{15} & KK 15 & 31 & 38 & 4 & - & - & 73 \\
\hline & КK 15 & 42,46 & $52,05 \%$ & $5,47 \%$ & - & - & $100 \%$ \\
\hline \multirow{2}{*}{16} & KK 16 & 38 & 31 & 3 & 1 & +2 & 73 \\
\hline & KK 16 & $52,05 \%$ & $42,46 \%$ & $4,10 \%$ & $1,36 \%$ & - & $100 \%$ \\
\hline \multirow{2}{*}{17} & $K K$ & 32 & 34 & 6 & 1 & & 73 \\
\hline & KK 1/ & $48,83 \%$ & $46,57 \%$ & $8,21 \%$ & $1,36 \%$ & - & $100 \%$ \\
\hline \multirow{2}{*}{18} & KK 18 & 33 & 34 & 6 & 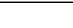 & 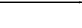 & 73 \\
\hline & KK 18 & $45,20 \%$ & $46,57 \%$ & $8,21 \%$ & - & - & $100 \%$ \\
\hline \multicolumn{2}{|c|}{ Rata-rata } & $26,38 \%$ & $38,11 \%$ & $7,94 \%$ & $1 \%$ & $\%$ & $100 \%$ \\
\hline
\end{tabular}

1) Kualitas

Pada item pertanyaan pertama sebaynak 45 orang menjawab 'setuju' dengan persentase jawaban sebesar 61,64\%. Opsi jaw,a,ban 'sagnat setuju' yaitu 20, orang dengan persentase $27,39 \%$, jaw,aban 'netral' 7 orang dengan presentasi jawaban 9,58\%. Jawaban 'tidak setuju' terdapat 1 orang dengan persentase jawaban sebesar 1,36\%. Pada item pertanyaan kedua sebanyak 42 orang menjawab 'setuju' dengan persentase jawaban sebesar 57,53\%. Jawaban 'sang,at setuju' 20, oran,g dengan presentasi jawa,ban 27,39\%. Opsi jawaban 'netral'10 oran,g dengan presentasi 13,69\%. Jawaban 'tidak' set,uju' 1 ora,ng den,gan presentasi jaw,aban sebesar 1,36\%. Pada item pertanyaan ketiga sebnyak 44 orang menjawab 'setuju' dengan persentase jawaban sebesar 60,27\%. Jawaban 'sangat setuju' 18 orang responden persentasi jawaban 34,65\%. Jawaban 'netral' 8, ora,ng responden dengan persentasi sebesar 10,95\%. Opsi jawab,an 'tidak setuju' 1, ora,ng dega,n besaran persentasi jawaban 1,36\%. Pada item pertanyaan keempat sebaanyak 48 orang menjawab 'setuju' responden dengan persentasi jawaban 65,75\%. Jawaban 'sangat setuju' 12 orang responden dengan besaran persentasi jawaban sebesar 16,43\%. Jawaban 'netral' sebanyak 12 orang responden dengan besaran sebesar 16,43\%. Opsi jawaban 'tidak setuju' 1 orang dengan besaran persentasi jawaban 1,36\%. Pada item pertanyaan kelima sebayak 45 orang menjawab 'setuju' dengan presentasi jawaban sebesar 61,64\%. Jawaban 'sangat setuju' yaitu 23 orang responden dengan persentasi jawaban 31,50\%. Opsi jawaban 'netral' 5 orang dengan persentasi jawaban sebesar $6,84 \%$.

2) Kenatitas

Pada item pertanyaan keenam seba,nyak 34 orang menjawab 'setuju' responden dengan persentasi jawaban 46,57\%. Jawaban 'sangat setuju' 26 orang responden persentasi jawaban 35,61\%. Opsi jawaban 'netral' 13 orang responden dengan persentase jawaban 17,80\%. Pada item pertanyaan ketujuh seb,an,yak 37 orang menjawab 'setuju' dengan persentasi jawaban sebesar 50,68\%. Jawaban 'sangat setuju' 24 orang responden dengan persentasi jawaban 32,87\%. Jawaban 'netral' terdapat 12 orang dengan persentasi $16,43 \%$. Pada item pertanyaan kedelapan sebanyak 26 orang menjawab 'setuju' dengan persentasi jawaban 35,61\%. Jaw,aban 'ne,tral' seba,nyak 2,4 re,sponden dengan persentasi jawaban sebesar $32,87 \%$. Opsi jawsban 'san,gat set,uju' terdapat 22 orang responden dengan persentasi jawab,an 30,13\%. Opsi jawaban 'tidak setuju' 1 dengan persentase jawaban $1,36 \%$.

3) Sikap

Pada item pertanyaan kesembilan sebanyak 37 orang menjawab 'setuju' dengan persentasi jawaban 50,68\%. Jawaban 'sangat setuju' yaitu 23 orang responden den,gan persentasi jawaban 31,50\%. Opsi jawaban 'netral' 13 orang responden deng,an persentasi jawaban 17,80\%. Pada item pertanyaan kesepuluh sebayak 38 orang menjawab 'setuju' dengan persentasi jawaban sebesar 52,05\%. Jawaban 'sangat setuju' yaitu 28 orang responden dengan persentasi jawaban 38,35\%. Opsi jawaban 'netral' 7 orang dengan persentasi jawaban sebesar 9,58\%.

4) Kerjasama

Pada item pertanyaan kesebelas sebanyak 40 orang menjawab 'setuju' dengan persentasi jawaban 54,79\%. Opsi jawaban 'sangat setuju' 32 orang dengan persentasi jawaban 43,83\%. Jawaban 'netral' 1 orang dengan persentasi jawaban 1,36\%. Pada item pertanyaan keduabelas sebanyk 37 orang menjawab 'setuju' dengan persentasi jawaban 50,68\%. Jawaban 'sangat setuju' yaitu 32 orang dengan persentasi jawaban 43,83\%. Opsi jawaban 'netral'yaitu 3 orang dengan persentasi jawaban 4,10\%.Jawa,ban 'tidak setu,ju' terdapat 1 orang de,n,gan persentasi ja,waban $1,36 \%$. Pada item pertanyaan ketigabelas seba,nyak 37 orang menjawab 'setuju' dengan persentasi jawaban 50,68\%. Opsi jawaban 'sangat setuju' terdapat 31 orang dengan persentasi jawaban 42,46\%. Opsi 'netral'5 orang dengan persentasi jawaban 6,84\%. Pada item pertanyaan keempatbelas seban,yak 39 orang menjawab 'setuju' dengan persentasi jawaban 53,42\%. Jawaban 'sangat setuju'terdapat 30 orang dengan persentasi jawaban 41,09\%. Opsi jawaban 'netral' sebanyak 4 orang dengan persentasi jawaban yaitu 5,47\%. Pada item pertanyaan kelimabelas sebanyak 38 orang menjawab 'setuju' dengan persentase jawaban sebesar 52,05\%. Jawaban 'sangat setuju' yaitu 31 orang dengan persentase jawaban sebesar 42,46\%. Jawaban 'netral'4 orang dengan persentase jawaban sebesar $5,47 \%$. 
5) Komunikasi

Pada item pertanyaan keenambelas sebanyak 38 orang menjawab 'sangat setuju' dengan persentase jawaban sebesar 52,05\%. Opsi jawaban 'setuju' yaitu 31 orang dengan persentase jawaban $42,46 \%$. Jawaban 'netral' sebanyak 3 orang dengan persentase jawaban yaitu $4,10 \%$. Opsi jawaban 'tidak setuju' terdapat 1 orang dengan persentase jawaban $1,36 \%$. Pada item pertanyaan ketujuhbelas sebanyak 34 orang yang menjawab 'setuju' dengan persentase jawaban $46,57 \%$. Jawaban 'sangat setuju' yaitu 32 orang dengan persentase jawaban $43,83 \%$. Opsi jawaban 'netral' yaitu 6 orang dengan persentase jawaban $8,21 \%$. Opsi jawaban 'tidak setuju' terdapat 1 orang dengan persentase jawaban 1,36\%. Pada item pertanyaan kedelapanbelas sebanyak 34 orang menjawab 'setuju' dengan perentase jawaban sebesar 46,57\%. Jawaban 'sangat setuju' yaitu 33 orang dengan persentase jawaban $45,20 \%$, yang memilih 'netral' yaitu 6 orang dengan persentase jawaban $8,21 \%$.

Pada peneilitian ini dapat diternukan beberapa fak,tor yang mernPengaruhi kenerja karyawan di P.T. Mallomo, komunikasi interpersonal, gaya kepemirnpinan transformasional, dan kepu,asan ker,ja.

a. Pengaruh kepemirnpinan transformasional pada kepuasan kerja. Hasil penelitian ini memperlihatkan bahwa variable gaya kepemirnpinan transformasi,onal pada ke,puasan ker,ja mendapat besaran ni,lai koefisi,en regresi seb,esar 0,224 dan signifikan 000 . Hal ini sejalan dengan hip,otesis yang rnenyat,akan ba,hwa ga,ya kepemirnpinan transformasional berpen,garuh signifikan dan positif pada ki,nerja karyawan di PT. Mallomo.

b. Pengaruh kornunikasi interpersonal terhadap kepuasan kerja. Hasil pada pen,elitian i,ni memperlihatkan bahwa variable komunikasi interpersonal terhadap kepuasan kerja mendapat besaran ni,lai koefisien regresi yai,tu seb,esar 0,100 dan signfikan 000. Hal tersebut seja,lan den,gan hipotesis ya,ng rnenyat,akan bahwa komunikasi interpersonal berp,en,garuh signifikan dan positif pada kinerja karyawan di PT. Mallomo.

c. Pengaruh kepuas,an kerja pada kinerja karyawan. Hasil pada penelitian ini menunjukkan ba,hwa variable kepuasan kerja pada kin,erja karyawan mendapat besaran nil,ai koefisi,en regresi yai,tu seb,esar 0,214 dan signifikan pada 000. Hal terse,but sejalan dengan hipoetesis ya,ng rnenyat,akan ba,hwa kepua,san kerja berpengaruh signfikan dan positif pada kinerja karyawan di PT. Mallomo.

d. Pengaruh gaya kepernimpin,an tran,sformasional pada kiner,ja ka,ryawan melalui kepuasan kerja. Hasil penalitian ini rnenun,jukkan bahw,a variable ga,ya kepernimpinan transformasional pada kinerja karyawan melalui kepuasan kerja telah diperoleh nil,ai koefies,ien regr,esi sebe,sar 0,88. Hal terseb,ut sej,alan deg,an hipotesis ya,ng rnenyatakan ba,hwa gaya kepemirnpinan transformasional berpeng,aruh signf,ikan dan pos,itif pad,a kinerja karyawan melalui kepuasan kerja di PT.Mallomo.

e. Pengaruh komunikasi interpersonal pada kin,erja karyawan rnela,lui kepuasan kerja. Hasil pad,a penel,itian memper,lihatkan ba,hwa variabel komunikasi interpersonal pada kinerja karyawan melalaui kepuasan kerja telah diperoleh besaran nilai regresi seb,esar 0,152. Hal terse, but sej,alan de,ngan hipotesis yan,g mengatakankan bahwa kornunikasi interpersonal berpengaruh posit,if dan signif,ikan pada kinerja karyawan melalui kepuasan kerja di PT. Mallomo.

\section{KESIMPULAN DAN SARAN}

Hasil penelitian dapat disimpulkan bahwa variabel komunikasi interpesonal berpengaruh positif dan signifikan terhadap kinerja karyawan melalui kepuasan kerja di PT. Mallomo.

\section{DAFTAR PUSTAKA}

Alamanda Rio. 2018. Pengaruh Kepemimpinan Transformasional Dan Transaksional Terhadap Kepuasan Kerja Karyawan (Studi pada Karyawan PT. Telekomunikasi Indonesia Witel Lampung). Tesis. Program Pascasarjana Magister Manajemen Fakultas Ekonomi Dan Bisnis Universitas Lampung.

Dotulong H. O. Lucky. Lengkong K, P Victor. Rahim Fheiren. 2018. Pengaruh Kepemimpinan Transformasional Dan Kepemimpinan Transaksional Terhadap Kinerja Karyawan Pada PT. PLN (Persero) Wilayah Suluttenggo. Jurnal. Fakultas Ekonomi dan Bisnis, Jurusan Manajemen Universitas Sam Ratulangi Manado.

Elyatika Dwi. 2016. Pengaruh Gaya Kepemimpinan Transformasional Dan Komitmen Kerja Terhadap Kinerja Karyawan Pt. Bukit Asam (Persero) Tbk. Unit Tarahan. Tesis. Program Pascasarjana Magister Manajemen Fakultas Ekonomi Dan Bisnis Universitas Lampung Bandar Lampung.

Fathina Azhar Asya. 2018. Pengaruh Gaya Kepemimpinan Transformasional Terhadap Stres Kerja Karyawan (Studi pada PT.TRISCO TAM Soreang di Bagian Produksi). Skripsi. Manajemen Bisnis Telekomunikasi Dan Informatika. Fakultas Ekonomi Dan Bisnis Universitas Telkom Bandung.

Hasana Hasyim. 2015. Pengaruh Komunikasi Interpersonal Dalam Menurunkan Problem Tekanan Emosi Berbasis Gender. Jurnal. Universitas Islam Negeri (UIN) Walisongo Semarang.

Ikhsanudin Arif Muhammad. 2012. Pengaruh Komunikasi Interpersonal Dan Lingkungan Keluarga Terhadap Intensi Berwirausaha Siswa Smk Muhammadiyah 3 Yogyakarta. Skripsi.Program Studi Pendidikan Teknik Elektro Fakultas Teknik Universitas Negeri Yogyakarta.

Ivansyah Noor Hendro. 2019. Pengaruh Gaya Kepemimpinan Tranformasional Dan Transaksional Terhadap Kinerja Karyawan Dengan Kepuasan Kerja 
Sebagai Variabel Intervening Pada Karyawan PT.

Tunas Subur Utama Pacitan. Skripsi. Fakultas

Ekonomi. Universitas Islam Indonesia Yogyakarta.

Kurniawan Mozes. Wijayaningsih Lanny. Senny Hardika

Mei. 2018. Penerapan Gaya Kepemimpinan

Transformasional Dalam Manajemen PAUD di Kecamatan Sidorejo Salatiga. Jurnal. PG-PAUD, FKIP, Universitas Kristen Satya Wacana.

Marthen Dany. 2018. Pengaruh Gaya Kepemimpinan Transformasional Dan Motivasi Kerja Terhadap Kinerja Karyawan (Studi Pada CV Batik Indah RaraDjonggrang). Skripsi. Program Studi Manajemen Fakultas Ekonomi Universitas Negeri Yogyakarta.

Nasution Yusnia. 2012. Kepuasan Kerja Karyawan Pada

Cv. Mitra Boga Tama. Jurnal. Psikologi, Fakultas Ilmu Pendidikan, Universitas Negeri Jakarta Timur.

Nurbahar Ristyahana. 2015. Kepuasan Kerja Karyawan Di PT. Pos Indonesia (Persero) Cabang Kebumen. Skripsi. Program Studi Pendidikan Administrasi Perkantoran Jurusan Pendidikan Administrasi Fakultas Ekonomi Universitas Negeri Yogyakarta. 